\title{
Tobacco industry strategies to undermine the 8th World Conference on Tobacco or Health
}

\author{
M E Muggli, R D Hurt
}

Tobacco Control 2003;12:195-202

See end of article for authors' affiliations .....................

Correspondence to: Richard D Hurt, MD, Nicotine Dependence Center, Mayo Clinic, 200 First Street, Southwest, Rochester, MN 55905, USA; rhurt@mayo.edu

Received 20 May 2002. Accepted 22 January 2003

\begin{abstract}
Objective: To demonstrate that Philip Morris and British American Tobacco Company attempted to initiate a wide ranging campaign to undermine the success of the 8th World Conference on Tobacco or Health held in Buenos Aires, Argentina, in 1992.

Data sources: Publicly available tobacco industry documents housed in Minneapolis, Minnesota, USA; Guilford, UK; on-line document websites; and telephone interviews with informed parties.

Study selection: Those documents determined to be relevant to the companies' campaigns against the 8th World Conference on Tobacco or Health.

Data extraction: Revision of chapter VIII of the July 2000 WHO report by a committee of experts, entitled: Tobacco company strategies to undermine tobacco control activities at the World Health Organization: report of the committee of experts on tobacco industry documents.

Data synthesis: Internal documents describe proposed media and science orientated campaigns developed by BAT, Philip Morris, and their consultants to divert attention away from the conference. Results and conclusion: This work shows that the tobacco industry has the resources and vested interest to combat perceived threats in its regional operating markets, in this case its Latin American market. It is important for the worldwide public heath community to become aware of the numerous ways in which the tobacco industry and its front groups can work against international tobacco control meetings, even including the manipulation of or working with other public health groups to oppose tobacco control efforts. Future world conference planners and participants should be aware that the tobacco industry is likely to continue to employ such methodology. There is no reason to think that the industry is paying less attention to such conferences in the present or future. Rather, it is likely the industry will adopt and expand strategies that were successful while abandoning those that were not effective. Required disclosure of financial support by all participants at all tobacco scientific conferences is recommended. For the tobacco control community, we also recommend careful coalition building and networking with other public health groups on the ways tobacco is implicated in other public health issues.
\end{abstract}

T here have been 11 World Conferences on Tobacco or Health (WCToH) thus far, all held in different locations and each with a diverse set of specific aims. The objectives of such conferences include strengthening global tobacco control efforts and reducing tobacco use worldwide. The 8th WCToH, held in Buenos Aires in 1992 and sponsored in part by the World Health Organization (WHO), was the first to concentrate on environmental tobacco smoke (ETS) and the effects of tobacco use in the developing world. It also was the first WCToH conference held in a developing country.

This review of tobacco company documents shows that Philip Morris and British American Tobacco Company (BAT) planned and to some degree initiated a wide ranging campaign to undermine the success of the 8th WCToH. It has previously been reported that the tobacco industry infiltrated the 6th WCToH and that Japan Tobacco sought to "change the very nature and tone" of that conference by having their consultants present "neutral" papers. ${ }^{12}$ Philip Morris and BAT, the two largest private tobacco companies, collaboratively sought to distract attention from the conference and embarrass its participants using an extraordinary range of tactics, some of which might be termed "dirty tricks". These included staging elaborate diversions from the conference and training journalists both to harass a conference participant and take over a WCToH press conference. According to BAT documents, a centrepiece of the plan to weaken the 8th WCToH was a media event aimed to distract attention from the WCToH to be produced with the unwitting help of the Pan American Health Organization (PAHO).
Throughout the campaign against the 8th WCToH, tobacco companies concealed their role by using outside scientists and journalists, and perhaps even PAHO, as vehicles of influence. In this paper, we present the wide ranging plans that the industry created and the narrower range of what was evidenced in the documents reviewed, press reports, and personal accounts as actually occurring. This work is important to the public health community because it demonstrates how seriously the tobacco industry takes perceived business threats, such as the 8th WCToH. It is difficult to confirm exactly which plans were implemented, partly because documents are incomplete, and partly due to the passage of time since the conference. Yet, the documentary evidence available nonetheless underlines the fact that the industry will go to great lengths to consider options to influence public opinion and protect its financial interests. As we describe in this paper, there is a strong indication that at least some of these plans were implemented.

Abbreviations: BAT, British American Tobacco Company; EPA, US Environmental Protection Agency; ETS, environmental tobacco smoke; $I A Q$, indoor air quality; IARC, International Agency for Research on Cancer; PAHO, Pan American Health Organization; TDC, an industry-affiliated resource group that replaced INFOTAB, Tobacco Documentation Centre; UNICEF, United Nations Children's Fund; WHO, World Health Organization; WCToH, World Conference on Tobacco OR Health 


\section{METHODS}

In October 1999 the Director General of the WHO appointed a committee to investigate whether the tobacco industry attempted to influence tobacco control activities at the WHO and other United Nations agencies. The inquiry by the committee of experts resulted in the July 2000 WHO report, entitled: Tobacco company strategies to undermine tobacco control activities at the World Health Organization: report of the committee of experts on tobacco industry documents. ${ }^{2}$ The committee of experts included the following people; Professor Thomas Zeltner, Director, Federal Office of Public Health, Switzerland; Dr David Kessler, Dean, Yale School of Medicine, USA; Dr Anke Martiny, Executive Director of Transparency International, Germany; Dr Fazel Randera, Inspector General of Intelligence, South Africa.

We have revised the chapter of the WHO report on the 8th WCToH and report its findings here.

The methodology used to access, search, and analyse the documents has been previously reported in detail. ${ }^{2}$ Briefly, publicly available documents housed in Minneapolis, Minnesota, ${ }^{3}$ Guildford, UK, ${ }^{4}$ and document websites on-line were searched. ${ }^{56}$ On-line and depository indices were searched using general terms such as "World Health Organization", "WHO", "PAHO", and specific search termsfor example, specific names, organisations, and strategies identified by the research team as relevant. Over 700 relevant documents were identified. The majority of the documents can be accessed at Tobacco Documents Online. ${ }^{6}$ Several individuals at WHO's Tobacco Free Initiative, Carlyle Macedo, former Director of PAHO, Paul Dietrich, media consultant who worked for Philip Morris and BAT, Ciro de Quadros, Director of Division of Vaccines and Immunizations at PAHO, and Richard Leclair, the Head of Information for PAHO from 1985-1995 and the Deputy Director and Senior Relations Office of WHO Liaison Office at the UN in 2000, were interviewed by telephone by the research staff of the WHO report. The interviewees were asked about documents in which they were named, about events that occurred or did not occur, and asked to shed light on any other information that was not clear from the documents alone.

\section{RESULTS}

The results are divided into two sections: (1) attempts to influence the media; and (2) attempts to influence the science. As some of the tactics were clearly implemented and others were not, we will clarify to the best of our knowledge those tactics that were carried out by presenting them at the beginning of each section. We will place less emphasis on those tactics that we are not certain were carried out by presenting them later in each section.

\section{Attempts to influence the media}

Paul Dietrich's overall plan

Paul Dietrich is a US attorney who has also worked as a publisher, writer, and consultant. Dietrich was the President of Catholic University's Institute for International Health and Development (IIHD), a non-profit body considering public health policy in developing nations. He was affiliated with two law firms in the 1990s: Jones, Day, Reavis and Pogue; and Squire, Sanders and Dempsey. The WHO investigation of the tobacco companies' influence on WHO showed that Dietrich wrote articles and editorials attacking WHO's priorities and travelled around the world for key tobacco companies, criticising WHO's priorities to journalists and governments. ${ }^{2}$

Dietrich was appointed to the development committee of PAHO in 1990. According to the documents, BAT and Philip Morris worked with Dietrich to develop a media programme aimed against the 8th WCToH. Dietrich has had a long term consulting relationship with Philip Morris and BAT. ${ }^{2}$ The media programme proposed by Dietrich ${ }^{78}$ was intended to promote the position that health spending in Latin America should not go to tobacco control initiatives, but rather to other pressing public health issues such as children's immunisation programmes. ${ }^{910}$ A BAT document with Dietrich's Washington DC address as letterhead estimated Dietrich's fees and personal costs associated with his plan were US\$67 200, while the total budget was $\$ 232781$. $^{11}$

Subsequent letters from BAT to Dietrich discuss this proposal in detail. The planned content of the media programme changed over time and consisted of some the following elements:

In "Phase I" of the Dietrich media plan interviews on the importance of childhood immunisation would be filmed with three individuals: Ciro de Quadros, the Director of Immunizations at PAHO, James P Grant, the Director of United Nations Children's Fund (UNICEF) and scheduled presenter at the 8th WCToH, and Raul Julia, the late Latin American actor involved in children's advocacy. ${ }^{8}$ According to a document written by BAT scientist Sharon Boyse:

\section{"A proposal by Paul Dietrich, an expert on $\mathrm{WHO}$ and a member of the development committee of the Pan Ameri- can Health Organisation, [is] to raise the profile of the question of health priorities in Latin America. This would be based on Paul Dietrich's argument (which has worked with $\mathrm{PAHO}$ ) that Latin American countries should not be spending money on tobacco programmes when a large proportion of children die from easily preventable diseases, and when there are still major health epidem- ics to be tackled such as the cholera outbreak. Essentially, this will involve making a TV programme with the head of the children's section at PAHO, Raul Julia, the Latin American actor who has campaigned on behalf of children, and possibly James Grant, the head of UNICEF. This programme would not specifically be linked to tobacco but it would be raised in the context of health priorities. This would then be 'sold' to a number of Latin American TV stations, and similar newspaper articles prepared and 'sold' to national newspapers, a week or two before the conference. This is very timely because the Latin American Ministers of Health are meeting at this time to discuss health priorities. ${ }^{12}$}

The videotaped interviews and written articles would then be edited for unwanted content before television media presentation. ${ }^{8}$ These interviews were to be funded by PAHO, which, according to the documents, was apparently an unknowing collaborator in the Philip Morris and BAT plan. ${ }^{13}{ }^{14}$ Sharon Boyse of BAT wrote:

"Our major advantage here has been our relationship with Paul Dietrich, a member of the development committee of the Pan-American Health Organisation [sic], the regional branch of the $\mathrm{WHO}$. Paul has long been a critic of WHO priorities in developing countries, arguing that they should not be proposing health spending on tobacco when, for example, children are still dying by the thousands from lack of easily obtainable and inexpensive vaccines and other medicines. For this reason, Paul has managed to persuade $\mathrm{PAHO}$ to take tobacco off their list of priorities for this year. We are therefore proposing a series of competing events, with $\mathrm{PAHO}$ sponsorship, on health priorities and in particular children's vaccination. ${ }^{\prime \prime}$

Dietrich's plan also called for misleading journalists about the origin of the interviews and thereby concealing the tobacco industry's role. The interviews would be offered to 
"journalist friends" with exclusive rights as long as they agreed to "prominently feature" all three interviews:

"We will tell them [the media] this is a project of Catholic University's, Institute for International Health and Development. According to the original proposal for the media plan, this will help them to preserve their journalistic 'integrity', so they don't feel they are flacking for multi-national corporations." 15

Although the planned videotaped interviews with Ciro de Quadros, the Director of Immunizations at PAHO, James Grant, and Raul Julia did not occur, ${ }^{16}$ press accounts from the time showed that a similar event did occur. During the 8th WCToH, James Grant, the Director of UNICEF, was reported to be involved in several press conferences, meetings with Argentinean officials, and other activities related to the importance of children's health in Latin American. ${ }^{17}$ A review of press accounts during the months preceding and during the conference showed that Grant's appearances on behalf of children's health received more coverage in the Buenos Aires press than the tobacco conference did. The publicly available documents searched for this review did not shed light on whether Dietrich played a role in Grant's appearances. Grant, who died in 1994, was never interviewed about his involvement.

\section{Gloria Estefan's "Save the children" tour}

When the Dietrich interviews previously described were rejected by Philip Morris on the grounds that the interviewees were not sufficiently well known in South America, ${ }^{18}$ the documents show that Dietrich offered an alternative. Popular US entertainer Gloria Estefan and Brazilian artist Xuxa would appear on a programme to publicly advocate for the importance of "vaccinating children" near the time of the conference. A letter from Dietrich to Philip Morris and copied to BAT states:

". . . [G]loria Estefan has agreed to appear on our program and to actually host the television special. She will also agree to be interviewed for the newspaper articles and her manager has agreed to allow us to use several songs from her most recent concert tour. We now envision a [sic] one-hour television program hosted by Gloria Estefan. We have tentatively titled the television program: 'Gloria Estefan's Save the Children.' Needless to say, Gloria Estefan is quite famous, not only in the United States but throughout Latin America." ${ }^{14}$

The television programme in which Gloria Estefan and other Latin American entertainers promoted childhood immunisations was produced in Miami. ${ }^{19}$ Repeated requests for copies of the tape were made to Estefan's publicist, however, no response was ever given. According to Dietrich, the Estefan special was televised throughout Latin America in primetime and also aired in the USA. Moreover, Dietrich said that the television event was sponsored by PAHO and that he wrote the original budget and business plan. ${ }^{20} \mathrm{He}$ called the show a "spectacular success". ${ }^{20}$

When asked whether this was done in direct competition with the 8th WCToH as the documents suggest, Dietrich replied that he did not think that was the case. He denied that BAT was involved in the media plan and PAHO denied that Dietrich was involved with PAHO's immunisation programme. He also denied that it was part of any strategy aimed at weakening the 8 th WCToH. ${ }^{20}$ PAHO officials acknowledged that the PAHO sponsored television special occurred, but disputed Dietrich's role in it. ${ }^{19}$ The Head of Information for PAHO from 1985-1995 said that Dietrich had no influence at PAHO on the
Development Committee, and that he assisted in all the meetings and that the issue of tobacco was never discussed. ${ }^{21}$ According to Ciro de Quadros, Director of PAHO's Division of Vaccines and Immunizations, Dietrich had "absolutely no influence" on the PAHO immunisation programme. ${ }^{22}$

\section{$\mathrm{PAHO}$ vaccination teleconference}

According to a letter from Dietrich to Philip Morris and copied to BAT, Dietrich discussed with BAT and Philip Morris a lengthy PAHO teleconference throughout Latin America aimed at focusing attention on the urgent need for a children's immunisation programme. The teleconference would take place 11 days before the World Conference. Dietrich's letter states:

". . . [T] he Pan American Health Organization ("PAHO") will spend $\$ 1.5$ million on a four-hour teleconference throughout Latin America promoting their new children's vaccination program. This live teleconference will be seen by over 40,000 health care workers in interactive teleconference centres throughout Latin America. The press will be invited in each country and PAHO plans to spend over $\$ 150,000$ promoting the conference to the press. $^{14}$

Dietrich reported in the same letter that the teleconference and Gloria Estefan's involvement would remedy any concerns the companies may have had regarding the media strategy's success.

"I believe this should satisfy some of the reservations that were expressed in Argentina. We now have a major media event around which to work. Secondly, we have a major star, who will attract large audiences. We have also been assured we will get early prime time airing of the television special on March 19th. All of this is perfectly timed for our initiative at the Eighth World Tobacco Conference. For the month leading up to the Tobacco Conference, all of the press will be focused on the major health priority in Latin America, which is to vaccinate all children." ${ }^{23}$

The letter states further that following the PAHO teleconference, Dietrich would speak to the Latin American Ministers of Health to report on its success and to get additional press coverage:

"PAHO has tentatively scheduled me to speak at the meeting of the Ministers of Health in Argentina to report on the success of the vaccine teleconference and the television special. . . This will give us another opportunity to hammer home this issue in the press in Argentina right in the middle of the Tobacco Conference." ${ }^{23}$

According to Ciro de Quadros, Director of the Division of Vaccines and Immunization at PAHO, the teleconference with health professionals did not occur. ${ }^{22}$

Use of PAHO's public relations firm

Dietrich used the same public relations firm for his media programme as PAHO did for the vaccination teleconference, to place articles on the teleconference in the media. In a document written by Dietrich, he said that the firm, Casals and Associates, gave him "complete editorial freedom" in writing any media articles:

"Casals and Associates have been hired by PAHO to handle all public relations for this teleconference. I have 
also agreed to hire Casals and Associates to promote our television special as well as to place newspaper articles in selected newspapers in the targeted countries. They have agreed that placing our newspaper articles and clips of the interviews on television news programs will have a first priority in terms of the overall public relations strategy to promote both the PAHO Teleconference and our television program. They understand that I will have 'complete editorial freedom' in writing the final articles which will be placed in the press." ${ }^{14}$

Though we do not have substantiation of this contract outside of these documents, this relationship appears to have occurred.

\section{AIDS campaign}

In addition to the media initiatives that the documents indicate were devised by Dietrich, industry officials proposed several other initiatives to divert attention from the conference, such as launching an AIDS campaign to coincide with the conference. The documents reflect plans to engage AIDS advocacy groups in Argentina to argue that health resources should be spent on AIDS related programs rather than on tobacco. An AIDS campaign would be launched. US basketball star Magic Johnson was to be approached and asked to appear on TV programmes and be involved in a press conference. BAT planned to have "publicity" films on AIDS projected on large screens in different areas in the city (Uptown, Belgrano, and Racolata) and to have government officials invited. AIDS foundations were to fund this project. ${ }^{24}{ }^{25}$ A letter from BAT's subsidiary in Argentina states:

\section{"Being the disease of the century and a preventive [sic] disease, AIDS should be 'public [enemy] No. 1' because of its terminal consequences at every age. Facing the [sic] AIDS increasing importance in the world and in Argentina we believe this disease to be the sole matter cable [capable] [sic] of eclipsing the Conference." 26}

Interviews and a search of local press coverage did not reveal that these specific public relations strategies occurred. However, there were two events that occurred in Buenos Aires at the time of the conference that were similar in nature to the strategies proposed by the industry. First, although an AIDS awareness campaign of the kind specifically described in the industry documents apparently did not occur, a similar AIDS related event did occur during the 8th WCToH. The Buenos Aires newspaper, La Prensa, reported that the Argentina Ministry of Health and Social Action launched a second phase of its National Program against AIDS on the last day of the 8th WCToH. Luc Montagner, one of the discoverers of HIV, was invited to Argentina to attend the press conference. ${ }^{27}$

\section{Journalists programme and congresses for Argentinean} reporters and tobacco manufacturers

"Phase II" of the Dietrich media programme called for journalists to promote an article questioning the 8th WCToH and health spending on tobacco programmes a few days before the conference. The original proposal for the programme written on letterhead with Dietrich's address states:

"1) We draft a sample article questioning the anti-tobacco conference and the funding of anti-tobacco programs, in light of the children that are dying for lack of vaccines and the PAHO program that needs over $\$ 50$ million dollars more in order to insure children don't die before the age of five, etc, etc ...

"2) We try to have one of our Argentinean journalist friends prominently print this article in his or her newspaper a day or two before the conference begins." ${ }^{15}$

In addition, "reliable" journalists would be brought to Argentina to cover the conference for the sole purpose of "creat[ing] a controversy". ${ }^{15}$

The original proposal states that a few days before the conference, the journalists would be trained by the tobacco companies to create diversions during press conferences:

"We must teach them [the journalists] how to be pushy and press the speakers aggressively (speakers will not want to compare spending on tobacco and funds for children. If they don't answer the question, our journalist must aggressively pursue the speaker with follow up questions until he finally addresses the issue - this will not be easy.) If we are successful in getting the journalists to be aggressive and work as a team, we should be able to dominate the press conference. Even if we only get a few journalists to write about the controversy we have created, I think this would be a success. We will also have succeeded in diverting the press conferences with 'our' questions, so they have less time to attack us." ${ }^{15}$

A forum for Argentinean reporters was suggested to take place a month before the conference to ensure that local reporters would receive industry messages about the economic importance of tobacco and PAHO priorities.

"It is proposed to hold a congress for outstanding reporters from the most important mass media and thus keep them informed about the socioeconomic importance of the tobacco growth, the actual scope and effect of the advertising restrictions in other countries, WHO statistics, priorities of the Pan American Health Office, etc. This congress should be held at least a month before the date corresponding to the 8th Conference so that the representatives of the various mass media may know opinions different from the ones to be spread by such Conference and thus be impartial at the time of publishing its conclusions." 28

A Latin American tobacco manufacturer's congress was suggested to be held immediately before the conference. At the congress, agricultural and economic officials and leaders of tobacco growing regions would be invited to hear about the economic importance of tobacco in those regions. ${ }^{29}$

"It is suggested to hold a meeting of tobacco manufacturers in early March 1992 to be attended by the Tobacco Chambers, the Tobacco Cooperatives and international tobacco institutions from all over the world ... .[The] meeting would deal with the economic and social importance of tobacco growth for local economies. An attempt will be made to: Invite officials from Agriculture and Economy; governors and union leaders of tobacco-producing provinces to attend this Congress. Have the Congress declared of national or provincial interest, depending on the case. Spread the conclusions arrived at the Congress in all the media. ${ }^{29}$

While it was not determined whether a congress for tobacco manufactures was held, a press account about WHO DirectorGeneral Nakajima's speech in La Prensa, during the last day of the conference, went on at great length about the economic importance of tobacco, suggesting that some journalists had been primed by the tobacco industry. ${ }^{30}$ 
8th WCToH abstract submissions relating to "individual freedoms"

Two or three papers were to be submitted to the 8th WCToH arguing that tobacco control efforts infringed on individual freedoms. Industry representatives assumed that such papers would be rejected. The plan was to publicly use this rejection as evidence that individual freedoms were indeed squashed, and also of the bias of the conference organisers.

\begin{abstract}
"Here the possibility is to have someone of importance send a report directly questioning the antismoking fight for considering it as an attack to individual liberty; for considering that these groups are prohibitionist, paternalist, retrograde and leading the report should extol the individual's freedom to do or refrain to do something according to his conscience, i.e., develop an eminently liberal thought and should repudiate the groups that seek to decide what the rest of people may or may not do. It is assumed this report will be immediately rejected, and this will provide even more reasons to prove how partial and prejudiced these groups are. If materialized, such rejection will have to be spread and made publicly known." 24
\end{abstract}

While several presentations were made with titles similar to this, there is no direct evidence outside the documents that they were presented by speakers supported by the tobacco industry. However, this was a tactic successfully used to "infiltrate" the 6th WCToH by presenting more "neutral" papers. ${ }^{12}$ In addition, the June 2000 WHO inquiry uncovered that a German cardiologist representing WHO at the 4th WCToH in Stockholm was associated with the tobacco industry and was reported, by industry consultant Peter Lee, to "severely criticize the spirit of the conference" in a statement, lending support to the "impression that the smoking problem should not be over-dramatized". ${ }^{231}$

Interviews and media searches did not provide evidence of other planned media activities occurring during the conference. The following is an accounting of those plans in which we found no evidence, outside of the plans described in the documents, of the events occurring.

\section{Campaign aimed at a US senator}

US Senator Edward Kennedy was scheduled to attend the conference. BAT reported that a campaign against Kennedy, outlining scandals associated with him in the USA, was planned to lessen his public impact on the conference. A letter from the BAT subsidiary in Argentina states:

\begin{abstract}
"Selected reporters will have to question his [Ted Kennedy's] alcoholic dependence and highlight the sexual harassing blamed on him in the USA, thus reducing the importance of his presence at the Conference. ${ }^{132}$
\end{abstract}

To our knowledge, Senator Kennedy did not attend the conference.

Football (soccer) match and President Jimmy Carter's visit A letter from Sharon Boyse states:

"There were a number of additional local proposals that were discussed, including a proposal to stage an international football [US soccer] match on a key press conference day to ensure that the major press attention is diverted to what the Argentinean public will consider to be a much more important subject. The formation of a smoker's rights group was discussed, as were various plans to infiltrate the conference organisation and the conference per se." 12

Former US President Jimmy Carter was scheduled to attend the 8th WCToH closing sessions. The staged football match was planned to divert attention from Carter's arrival for the conference. The match between an American and Spanish team would be organised to take place as he arrived in Argentina. ${ }^{12}{ }^{33}$ According to a document that appears to come from an Argentinean tobacco company official:

"A football match should be organized with a combined American team and the Spanish team. This sporting event is supposed to take place on the day Jimmy Carter arrives in our country, so as to reduce the journalistic coverage of his arrival. The match should be transmitted live on TV and national authorities should be invited." 33

Carter's appearance was cancelled sometime during the conference and we found no evidence of a football match occurring during the time of the conference.

\section{Cultural programme}

An event or campaign to coincide with the 8th WCToH entitled: "The international importance acquired by the original American growths" was also proposed emphasising the cultural and historical importance of tobacco and other products grown in Latin American countries. ${ }^{34}$ The proposal suggested the following:

"The objective must tend to provide a new value to the original American growths (tobacco, corn, cacao, etc.) to point out the importance and the development level these products had in the indigenous communities as well as their later popularization and spreading in the whole world . . . This campaign should be started on October 12, 1991, and be intensified in March 1992." ${ }^{34}$

\section{Attempts to influence the science}

Philip Morris and BAT developed scientific strategies to thwart any smoke-free policies that would result from the 8th WCToH. Primary strategies involved a scientific consultant programme in Latin America and an indoor air quality conference to be held at the time of the conference.

Latin American ETS consultant programme

A Latin American ETS consultant programme was developed in part because ETS was thought to be an important issue at the 8th WCToH. A letter from Sharon Boyse of BAT states:

"Since we know that ETS will be a major issue [at the Conference] we have developed a regional ETS consultancy programme so that we now have scientists in key countries who will speak up about ETS."

More specifically, the consultant programme was created to mitigate possible smoking bans resulting from the conference. Philip Morris, BAT, and the US law firm of Covington and Burling selected and trained Latin American scientists for this initiative. This "regional" initiative was part of a larger, previously detailed ETS consultant programme, managed by Covington \& Burling under the direction of Philip Morris and BAT, in European, Asian, Nordic, Latin American and US markets where the companies operated. ${ }^{135-37}$

According to a letter from Sharon Boyse, many of the scientists already possessed public relations skills.

"The ETS consultants from the consultancy programme . . .will be used in programmes designed to 
indicate that smoking restrictions (known to be one of the most likely recommendations of the conference) are unnecessary . . The first stage of the ETS consultancy programme has been completed and consultants identified in all target countries except Ecuador. Many consultants are already skilled in media techniques, including one scientist in Venezuela who is a motor racing commentator in his spare time! The consultants will be brought together for an initial training and orientation session in early September, and both BAT and PM supporting companies will have a meeting in Miami on October 21-25 with Covington \& Burling to discuss implementation of the programme and activities that the consultants could undertake." 12

It is undetermined whether the Indoor Air Congress occurred during the time of the conference. In Argentina, one of the industry paid consultants was a prominent Buenos Aires cardiologist, Dr Carlos Alvarez, who was also a personal scientific and technical advisor to the then Argentine President Carlos Menem. Latin American ETS consultants were also scheduled to publish articles relating to ETS and indoor air quality in the Argentinean popular press and attend scientific symposia on behalf of the industry in March of 1992.

\section{Meeting with conference organisers}

Not only do the documents suggest that the tobacco companies attempted to manipulate the public reporting of the conference through Dietrich's media programme and other independent initiatives, but documents also show that BAT sought to secretly influence the scientific debate during the conference. The industry prepared for the 8th WCToH by meeting with the conference organisers before the conference. A member of a BAT subsidiary met with the President of the 8th WCToH, Jorge Alberto Pilheu. He was told that Pilheu wanted to concentrate on a scientific discussion on tobacco use and disease and engage in less "politicking". The industry responded by planning to recruit scientists who would appear independent from the industry to infiltrate the conference and give speeches at national medical organisations. According to an official from the BAT subsidiary in Argentina, NoblezaPicardo:

"This [Pilheu's conference agenda] provides a unique opportunity that has not existed in previous conferences which is to present top level scientists whose conclusions differ from those generally reached by participants of these meetings. With proper press handling we could, for the first time, create a controversy in areas in which public opinion is under the impression that none exists. This, of course, requires that we are able to achieve the participation of top level scientists or academics, doctors, biostaticians, with sound reputations in the USA or the UK. Furthermore, they would have the chance of making speeches at the National Academy of Medicine and at the Medical Association of Argentina. The industry, obviously, can not [sic] appear to sponsor the activity nor finance participant's trips. That would have to be done through donations to foundations or independent institutions.

"Before advancing on this subject, we would very much appreciate your opinion as to the possibility of getting relevant scientists from abroad to accept this task. Dr Pilheu thinks that it would be most favourable if they were already known for opinions that differ from those of personalities such as [Sir] Richard Doll or R. [Richard] Peto. ${ }^{138}$ [emphasis added]
This seems contrary to one of Dr Piheu's stated goals published in the conference programme:

"This Conference will be the beacon that will enlighten the world's cardinal points. The words enunciated here will have a strength that will be heard all over the world because they are full of truth; because they are logical; because they are positive. ${ }^{139}$

Just as with the 6th WCToH, the documents do not reveal which tobacco company sponsored scientists attended the 8th WCToH. ${ }^{1}$

\section{Industry monitors}

Industry monitors were employed to attend the conference committee organisation meetings and to attend the conference itself. ${ }^{32}$ The monitoring teams ranged from Tobacco Documentation Centre staff $\mathrm{f}^{40-45}$ (an industry affiliated resource group that replaced INFOTAB) to specialised monitors with medical backgrounds. A document from an industry official described the monitoring:

"[One person] will get acquainted with the aspects of the Conference regarding publicity, logistics and diffusion by means of the media. The other person, being a Medical Doctor will be concerned with the scientific aspects of the Conference. The object is to get the necessary information by the time the Conference is taking place and also acknowledge the degree of diffusion they intend to give this Conference." ${ }^{\prime \prime 2}$

It is clear from the documents that tobacco companies did have professional monitors attend the conference and generate daily reports. ${ }^{40-45}$

\section{Indoor air quality seminar}

An industry official also proposed to hold an indoor air quality (IAQ) seminar where sick building syndrome and indoor air quality would be discussed. ${ }^{46}$ The seminar was to be developed to divert media attention from the WCToH:

"The . . congress would have to be held almost simultaneously to the 8th Conference so that the spreading of both events meets and overlaps in all the media. ${ }^{146}$

It is undetermined whether the indoor air conference occurred during the time of the 8th WCToH. Consultants from the ETS consultant programme did, however, create Indoor Air International, a technical group of scientists addressing IAQ issues that held several conferences and produced its own journal. ${ }^{36}$ The tobacco industry's hand in funding and creating the IAI was not public.

\section{DISCUSSION}

It is important for worldwide public heath communities to become aware of the numerous ways in which the tobacco industry and its front groups can work against international tobacco control meetings, even including the manipulation of or working with other public health groups to oppose tobacco control efforts. The documents reviewed demonstrate the extraordinary lengths to which leading tobacco manufacturers will go to undermine the success of just one WCToH held in Argentina. Many of the tactics proposed by tobacco companies had elements of a "dirty tricks" campaign. However, these tactics, and many others devised by industry representatives in connection with the 8th WCToH, also had a more significant purpose: to distract media attention from the conference and manipulate the media stories that emerged. Industry representatives attempted to discredit the 8th WCToH by staging 
events promoting the importance of children's immunisation and AIDS. The tobacco companies then attempted to orchestrate a media response that would unfavourably contrast the need for tobacco control with the need for childhood immunisation and AIDS prevention.

Why should the tobacco control community care what happened at the 8th WCToH in Argentina in 1992? Since the tobacco industry document collections are most complete up until the mid-1990s, by learning what the tobacco industry planned from these documents, we can have a clearer picture of what happened and also to be more alert for similar tactics to occur in the future such as the 12th WCToH in Helsinki in 2003. There is no reason to believe that the tobacco industry is paying less attention as time goes on. In fact, there is every reason to believe the industry will try to do even more in the future as smoking restrictions and financial losses due to litigation increase.

The tobacco companies' planned use of the media in this context deserves special mention. In this campaign, journalists were to play a central and, in some cases, a knowing role in the manipulation of public opinion. Not only did industry representatives expect to plant, under the byline of local journalists, articles actually written by the industry representatives or consultants, they expected to be able to "train" local journalists to harass a conference participant and disrupt a press conference. This internal disclosure of the care and feeding of journalists is in line with observations made by Kennedy and Bero in the US print media between January 1981 and December 1994 that: (1) the number of newspaper and magazine articles reporting on secondhand smoke increased; (2) $62 \%$ of articles concluded that research on ETS is controversial; and (3) tobacco industry representatives were quoted significantly more in newspapers than in magazines. ${ }^{47}$

The documents reported here also suggest that industry representatives may have made use of PAHO in its campaign. Under the auspices of Paul Dietrich, the tobacco companies may have been able to guide the development of, and then exploit, a PAHO sponsored media programme, for the purpose of undermining the 8th WCToH, although this is disputed by Dietrich and PAHO officials. Previous tobacco document research has also demonstrated the importance of independent consultants who have a connection with agencies such as WHO or the International Agency for Research on Cancer (IARC) and who do not disclose their relationship with the tobacco industry. Like Paul Dietrich, the industry benefited from its consultant, Dr Gaston Vetorazzi, for setting tar and nicotine measurement standards ${ }^{48}$ and in responding to a regulatory threat against a controversial class of tobacco pesticides. $^{2}$ Tobacco companies have also hired or offered employment to former WHO or UN officials in an effort to gain intelligence and take advantage of their contacts within the organisations. ${ }^{2}$ Efforts to undermine the 1993 IARC monograph on secondhand smoke also employed industry consultants who lobbied WHO scientists and generated intelligence for the tobacco companies. ${ }^{237}$

Organisers of future conferences should be aware of the pervasive attempts by the tobacco industry to influence the content and publicity of the 8 th WCToH. Previous reports have disclosed budgetary information for elaborate industry campaigns developed to undermine health and government agency efforts to research the harmful effects of secondhand smoke. Ong and Glantz reported that Philip Morris budgeted, at a minimum, \$2 million for plans relating to the IARC ETS monograph for one year, versus the \$1.5-3.0 million estimate spent for the entire 10 year IARC study. ${ }^{37}$ Muggli and colleagues reported that Philip Morris spent over \$16.5 million on the "scientific" portion of their campaign against the ETS issue in the year between the first draft and final release of the 1993 EPA risk assessment on secondhand smoke and that the 1996 Philip Morris media affairs ETS/EPA budget was near twice the amount allocated for youth access initiatives and US

\section{What this papers adds}

Previous findings from internal tobacco company documents have evidenced elaborate public relations campaigns designed to subvert tobacco control efforts around the world. Many of these strategies could be carried out only through the use of media and scientific consultants whose affiliation with the tobacco industry was never disclosed.

Documents reported here show that Philip Morris, British American Tobacco, and their consultants proposed a wide ranging campaign to undermine the success of the 8th World Conference on Tobacco or Health (WCToH) held in Buenos Aires, Argentina, in 1992. These included staging elaborate diversions from the conference and training journalists both to harass a conference participant and take over a WCToH press conference. A centrepiece of the plan to weaken the 8th WCToH was a media event aimed to distract attention from the WCToH to be produced with the unwitting help of the Pan American Health Organization (PAHO). Throughout the campaign against the 8th WCToH, tobacco companies concealed their role by using outside scientists and journalists as vehicles of influence. Regardless of whether the plans were implemented, the documents show that the industry will go to great lengths to influence public opinion and protect its financial interests. In fact, there is every reason to believe the industry will try to undermine international tobacco control efforts in the future as smoking restrictions and financial losses due to litigation increase.

Food and Drug Administration regulatory issues. ${ }^{1}$ It is, therefore, imperative that presenters and organisers be required to make full disclosures of financial contributions to work presented at scientific conferences. Our findings also support the importance of coalition building and networking with other public health groups on the ways tobacco is implicated in other public health issues.

Although the limitations of document research have been previously reported, ${ }^{12}{ }^{49}$ the confines of describing the events found in internal tobacco company documents reported here is apparent. The documents tell only part of the story. Every effort was made to follow up on proposed plans; however, dated proposed campaigns and the reliance on interviewee's memories made following up difficult. Regardless of the limitations inherent in document research, we believe that documenting proposed actions and internal communication between members of the tobacco industry remains a valuable tool in combatting industry strategy to undermine tobacco control efforts.

\section{ACKNOWLEDGEMENTS}

We would like to thank Ann Witt for her direction and support of the development of this case study. We would also like to thank the other members of the research staff of the WHO inquiry, Doug Blanke, Abigail Halperin, Nadine Rae Leavell, Andy Rowell, Joshua Sharfstein, Judith Watt, Derek Yach for his contribution to the WHO inquiry, and to Ann B Peterson for her editing and formatting assistance. This work was supported in part by NIH grant R01 CA90791: "Tobacco Industry Documents on ETS - The Next Front."

\section{Authors' affiliations}

M E Muggli, St Paul, Minnesota, USA

R D Hurt, Mayo Clinic, Nicotine Dependence Center, Rochester, Minnesota, USA

\section{REFERENCES}

1 Muggli ME, Forster JL, Hurt RD, et al. The smoke you don't see: uncovering tobacco industry scientific strategies aimed against environmental tobacco smoke. Am J Public Health 2001 ;91;1419-23. 
2 Anon. Tobacco company strategies to undermine tobacco control activities at the World Health Organization: report of the committee of experts on tobacco industry documents. July 2000. URL:

http://www.tobacco.who.int/repository/stp58/who_inquiry.

3 Minnesota Tobacco Document Depository, Hennepin Business Center, 1021 10th Avenue SE, Suite 1021, Minneapolis, MN USA 55414, Phone: (800) 526-8886, Email: Mndep@aol.com

4 British American Tobacco Document Depository. Globe House 4 Temple Place, London, UK WC2R 2PG, Fax: 442078452783 Requests for admission to the depository should be faxed to the BAT Legal Department.

5 The Tobacco Archives. Accessed June 2000. URL: http:// www.tobaccoarchives.com.

6 Tobacco Documents Online (TDO). Accessed June 2000. URL: http://www.tobaccodocuments.org/guildford_misc/.

7 Grant E. 2 September 1991. British American Tobacco Company. Bates No. 304003991-3992. Guildford Document Depository. URL: www.tobaccodocuments.org/guildford_misc/.

8 Agenda. 10 July 1991. British American Tobacco Company. Bates No. 300504351-4353 at 4351. Guildford Document Depository. URL: www.tobaccodocuments.org/guildford_misc/.

9 Boyse S. 8th World Conference on Tobacco and Health. 28 August 1991. British American Tobacco Company. Bates No. 202019292-9293 at 9292. Guildford Document Depository. URL: www.tobaccodocuments.org/guildford misc/.

10 Boyse S. Visit to Argentina, 29-30 July 1991 and update on activities in South America. 8 August 1991. British American Tobacco Company. Bates No. $304004032-4034$ at 4032. Guildford Document Depository. URL: www.tobaccodocuments.org/guildford_misc/.

11 Agenda. 10 July 1991. British American Tobacco Company. Bates No. 300504351-4353 at 4353. Guildford Document Depository. URL: www.tobaccodocuments.org/guildford_misc/.

12 Boyse S. Visit to Argentina, 29-30 July 1991 and update on activities in South America. 8 August 1991. British American Tobacco Company. Bates No. 304004032-4034. Guildford Document Depository. URL: www.tobaccodocuments.org/guildford_misc/.

13 Hazel P. 20 August 1991. British American Tobacco Company. Bates No. 304004009. Guildford Document Depository. URL: www.tobaccodocuments.org/guildford misc/.

14 Dietrich P. 6 September 1991. British American Tobacco Company. Bates No. 300516109-6111 at 6110 . Guildford Document Depository. URL: www.tobaccodocuments.org/guildford_misc/.

15 Agenda. 10 July 1991. British American Tobacco Company. Bates No. 300504351-4353 at 4352. Guildford Document Depository. URL: www.tobaccodocuments.org/guildford misc/.

16 Telephone interview with Paul Dietrich, 5 May 2000

17 Llega el director del UNICEF, James Grant. La Prensa. 30 March 1992:5.

18 Grant E. 2 September 1991. British American Tobacco Company. Bates No. 304003991-3992 at 3991. Guildford Document Depository. URL: www.tobaccodocuments.org/guildford_misc/.

19 Telephone interview with Carlyle Macedo, 15 May 2000.

20 Telephone interview with Paul Dietrich, 11 May 2000.

21 Telephone interview with Richard Leclair, 3 May 2000.

22 Telephone interview with Ciro de Quadros, 11 May 2000.

23 Dietrich P. 6 September 1991. British American Tobacco Company. Bates No. 300516109-6111 at 6111. Guildford Document Depository. URL: www.tobaccodocuments.org/guildford_misc/.

24 8th International Conference on Tobacco and Health. Proposed possible action to take against it. Undated. British American Tobacco Company. Bates No. 300504152-4157 at 4156. Guildford Document Depository. URL: www.tobaccodocuments.org/guildford_misc/.

25 Dastugue J. 8th World Conference on Tobacco and Health. British American Tobacco Company. 13 January 1992. Bates No. 300504295-4298 at 4298. Guildford Document Depository. URL: www.tobaccodocuments.org/guildford_misc/.

26 Dastugue J. 8th World Conference on Tobacco and Health. British American Tobacco Company. 13 January 1992. Bates No. 300504295-4298 at 4297. Guildford Document Depository. URL: www.tobaccodocuments.org/guildford misc/.

27 Se Realizo el lanzamiento del programa 'EI SIDA esta aqui.' La Prensa. 3 April 1992:7
28 8th International Conference on Tobacco and Health. Proposed possible action to take against it. Undated. British American Tobacco Company. Bates No. 300504152-4157 at 4155. Guildford Document Depository. URL: www.tobaccodocuments.org/guildford_misc/.

29 8th International Conference on Tobacco and Health. Proposed possible action to take against it. Undated. British American Tobacco Company. Bates No. 300504152-4157 at 4135. Guildford Document Depository. URL: www.tobaccodocuments.org/guildford_misc/.

30 Por causa del.tabaquismo mueren cada ano 3 millones de personas. La Prensa. 3 April 1992:10.

31 Lee PN. Dr. Helmut Schievelbein. 9 August 1979. Philip Morris Companies, Inc. Bates No. $2501159889-9891$ at 9889. URL: www.pmdocs.com.

32 Dastugue J. 8th World Conference on Tobacco and Health. British American Tobacco Company. 13 January 1992. Bates No. 300504295-4298 at 4296. Guildford Document Depository. URL: www.tobaccodocuments.org/guildford_misc/.

33 8th International Conference on Tobacco and Health. Proposed possible action to take against it. Undated. British American Tobacco Company. Bates No. 300504152-4157 at 4157. Guildford Document Depository. URL: www.tobaccodocuments.org/guildford_misc/.

34 8th International Conference on Tobacco and Health. Proposed possible action to take against it. Undated. British American Tobacco Company. Bates No. 300504152-4157 at 4153. Guildford Document Depository. URL: www.tobaccodocuments.org/guildford misc/.

35 Drope J, Chapman S. Tobacco industry efforts at discrediting scientific knowledge of environmental tobacco smoke: a review of internal industry documents. J Epidemiol Community Health 2001;55;588-94.

36 Muggli ME, Hurt RD, Blanke DD. Science for hire: a tobacco industry strategy to influence public opinion on secondhand smoke. Nicotine \& Tobacco Res (in press).

37 Ong EK, Glantz SA. Tobacco industry efforts subverting International Agency for Research on Cancer's second-hand smoke study. Lancet 2000;355; 1253-59

38 Dastugue J. 8th World Conference on Smoking and Health. 14 June 1991. British American Tobacco Company. Bates No. 304004077-4078 at 4077. Guildford Document Depository. URL: www.tobaccodocuments.org/guildford_misc/.

39 8th World Conference on Tobacco or Health Scientific Program booklet. "Welcome" statement from Jorge Alberto Pilheu, President of the 8th World Conference on Tobacco or Health.

40 Tobacco Documentation Centre. 8th World Conference on Tobacco or Health-Report No. 1. 29 March 1992. Philip Morris Companies, Inc. Bates No. 2503002532-2533. URL: http://www.pmdocs.com.

41 Tobacco Documentation Centre. 8th WCTH-Argentina. Tuesday, 31 March 1992. Report 3. 31 March 1992. RJ Reynolds Tobacco Company. Bates No. $512722156-2159$. URL: http://www.rirtdocs.com

42 Tobacco Documentation Centre. 8th WCTH-Argentina. Wednesday, 1 April 1992. Report 4, part 1. 1 April 1992. RJ Reynolds Tobacco Company. Bates No. 515722160-2166. URL: http://www.rirtdocs.com.

43 Tobacco Documentation Centre. 8th WCTH-Argentina. Wednesday, April 1992. Report 4, part 2. 1 April 1992. Philip Morris Companies, Inc. Bates No. 2503002435-2437. URL: http://www.pmdocs.com.

44 Tobacco Documentation Centre. 8th WCTH-Argentina, Tuesday, 2 April 1992. Report 5, part 2. 1 April 1992. Philip Morris Companies, Inc. Bates No. 2503002476-2478. URL: http://www.pmdocs.com.

45 Tobacco Documentation Centre. 8th WCTH-Argentina. Friday, 3 Apri 1992. Report 6, part 1 and part 2. 3 April 1992. Philip Morris Companies, Inc. Bates No. 2503002422-2430. URL: http://www.pmdocs.com.

46 8th International Conference on Tobacco and Health. Proposed possible action to take against it. Undated. British American Tobacco Company. Bates No. 300504152-4157 at 4154. Guildford Document Depository. URL: www.tobaccodocuments.org/guildford misc/.

47 Kennedy G, Bero L. Print media converage of research on passive smoking. Tobacco Control 1999;8;524-60.

48 Bialous SA, Yach D. Whose standard is it anyway? How the tobacco industry determines the International Organization for Standardization (ISO) standards for tobacco and tobacco products. Tobacco Control 2001:10:96-104

49 Malone R, Balbach E. Tobacco industry documents: treasure trove or quagmire? Tobacco Control 2000;9:334-8 